\title{
PERFIL
}

\section{Dr. José Manuel Borgoño El último de los mohicanos}

MARIEL SAGREDO(1)

Con más de medio siglo de actividad nacional e internacional en salud pública, el Dr. José Manuel Borgoño se considera un privilegiado y se autodefine como "el último de los mohicanos". A mediados del siglo pasado, un grupo de directivos del Ministerio de Salud se llevó a gente joven a trabajar con ellos: "Soy el último de ese grupo. Tuvimos una formación privilegiada que es muy difícil de obtener ahora en Chile", dice.

"Viví un momento excepcional de la historia de la medicina y de la salud pública en Chile, en el cual quienes nos educaban no sólo eran profesores que dominaban sus materias, sino personas que trans. mitían valores; fueron modelos que realmente quisimos imitar", expresa. En ese sentido, destaca que no es que el país se esté estancando en esta área: "Chile siempre progresa en medicina y salud, la diferencia es la velocidad".

Agrega que esa valiosa formación que recibió lo comprometió con la salud pública y le permite hoy sentirse orgulloso de haber aportado activamente a la transición epidemiológica y demográfica en nuestro país, así como haber gestado programas de inmunizaciones que erradicaron la viruela y la poliomelitis y eliminaron el sarampión. También señala su participación, junto a otros especialistas, en el control epidemiológico eficaz de la tuberculosis.

\section{DE LA UC A LA CHILE}

Si bien inició sus estudios de medicina en la Pontificia Universidad Católica, los concluyó en la Universidad de Chile y es en esta casa de estudios,

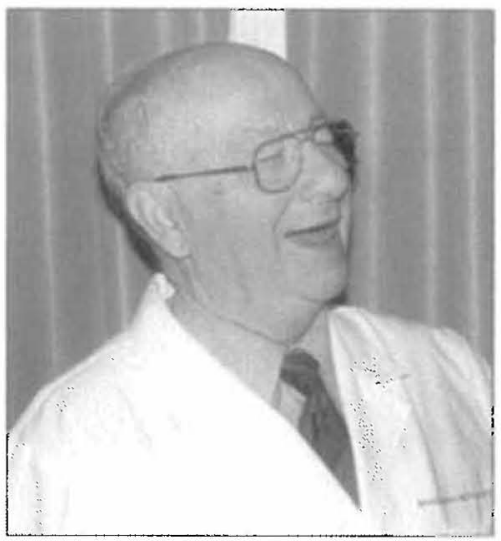

donde ha permanecido durante más de cinco décadas haciendo un valioso aporte en docencia y en la dirección de los más diversos programas que le ha correspondido encabezar. Hoy, a sus casi 80 años, es el Director del Campus Clínico Sur y académico del Departamento de Atención Primaria y Comunitaria, donde prepara especialistas en salud familiar.

Por su larga trayectoria, en mayo fue homenajeado por su Universidad, como una forma de reconocer su permanente compromiso y dedicación. En la oportunidad, el doctor Jorge Las Heras, decano de la Facultad de Medicina, señaló: "El doctor Borgoño ha ofrecido años maravillosos de su vida a esta Facultad, ha asumido desafíos y ha logrado grandes éxitos. Nosotros, como familia académica, le agradecemos de manera simbólica su esfuerzo a través de una medalla y un diploma pero, lo más importante, le decimos que siempre estaremos con usted".

Su labor como docente se inició en la escuela de enfermería de la Facultad y en la cátedra de enfermedades infecciosas de los profesores Horwitz y Kraljevic, en el año 1952. A partir de 1964 y hasta 1972, se ocupó, simultáneamente, de la docencia de medicina preventiva de los alumnos de las universidades Católica y de la Chile, que estaban en el Hospital Barros Luco.

También, desde hace más de tres décadas, se desempeña como profesor invitado en Epidemiología, en la Escuela de Salud Pública, entidad con la que mantiene estrechas relaciones docentes y académicas.

A comienzos de la década del 60, enfrentó con

"1. Editora Revista Chilena de Salud Pública. msagredo@komunicacl 
éxito un nuevo desafío. La Universidad de Chile le encargó la tuición de la formación de los becarios en el Ministerio de Salud. Además, de cumplir con el curso de magíster en la Escuela de Salud Pública, posteriormente estos becarios fueron formados en los departamentos de salud pública de la facultad y, actualmente, en la Escuela.

Otro desafío importante que se le encargó, fue la formación desde 1990, de los especialistas en salud familiar de la facultad.

Reconoce el Dr. Borgoño que en su vida han sido las circunstancias las que lo han dirigido profesionalmente. Cuenta que apenas se recibió y estaba a punto de casarse, fue a hablar con el jefe sanitario de ese entonces, el Dr. Hernán Urzúa, quien le comentó que requerían a alguien que se hiciera cargo de la jefatura del Distrito Sanitario Oriente (que reunía a los servicios de salud oriente y sur oriente). Allí inició su larga y fructífera cartera en salud pública: "parece que lo hice muy bien y cuando los servicios se unieron para constituir el Servicio Nacional de Salud, el 52` formé parte de su dirección general hasta que éste se acabó. Durante 28 años ocupé todos los cargos menos los políticos", comenta. Su labor en el SNS, la complementó en el Minsal, donde fue funcionario durante 41 años. "Serví a 23 ministros de salud en forma continuada", acota.

Padre de tres hijos, el Dr. Borgoño cuenta que sólo logró entusiasmar al más pequeño con la me. dicina, pero una vez licenciado optó por el sacerdocio.

\section{SU APORTE INTERNACIONAL}

Historia aparte es su largat experiencia internacional en la OPS/OMS. Aunque abarca más de treinta años (1964-1998), se encarga de resaltar que "nunca fui funcionario, fui siempre consultor y representé a Chile. Fue una labor muy gratificante y fecunda", rememora el Dr. Borgoño con alegría. Más aún declara ser "el único chileno que ha asistido a veinticinco asambleas mundiales seguidas; he sido presidente de todos los cargos de los cuerpos directi- vos de ambas instituciones y he pertenecido a ocho comité de expertos en la OMS; entre otras múltiples funciones". Asimismo, ha sido consultor en epidemiología y salud pública en 16 países en las cinco regiones de la OMS.

Su aporte internacional, ha sido reconocido, entre otros, por el Fondo de Naciones Unidas para la Infancia por su destacada labor en el campo de la salud pública infantil, distinción otorgada en 1985; recibió la Medalla de Salud para Todos de la OMS en 1988, siendo el único chileno al que se le ha otorgado a título personal en Chile; y el Premio Centenario de la OPS que obtuvo el 2002 por su trabajo internacional a favor de la salud de la Región de las Américas.

Pero una de las acciones que más lo contenta de su larga labor internacional es haber firmado -en representación de nuestro país- el acta de erradicación de la viruela en Ginebra, en 1980.

Pero su compromiso con la salud, es mucho más profundo y tiene otras vertientes. Desde hace más de cuarenta años, el Dr. José Manuel Borgoño ha asumido como propia la tarea de rehabilitar a niños lisiados. Así, ha ocupado cargos directivos en Chile y Latinoamérica en organizaciones de este tipo. Primero en la Sociedad Pro- Ayuda al Niño Lisiado y luego en la Fundación Teletón: "Durante mis trece años de presidencia en ambas instituciones, se construyeron siete de los nueve institutos que hoy tienen". Hoy es presidente de la Fundación Josefina Martínez de Ferrari, que cuenta con un hospital de cuarenta camas dedicadas a las enfermedades pulmonares crónicas de la infancia.

"Cuando uno recibe mucho tiene que dar todo a cambio, ese es nuestro deber como profesionales y como personas", dice y sonríe al recordar que el peso de los genes es fuerte, cuando se tiene entre los antepasados al Dr. Manuel Barros Borgoño, ex decano de la facultad de medicina y ex rector de la Universidad de Chile, y a monseñor Carlos Casanueva, ex rector de la $U C$.

Así, ningún día deja de acudir al campus sur de la Facultad de Medicina, ya que la docencia y el compromiso con la Universidad son actividades que-reconoce- disfrutar "enormemente". 